\title{
SISTEM PEMBINAAN DAN PENGEMBANGAN KOLEKSI DI PERPUSTAKAAN STIKES MEGA RESKI MAKASSAR
}

\author{
Akbar \\ Noerjihad Saleh \\ Muliaty Amin
}

\begin{abstract}
Abstrak: Tulisan ini akan mengungkapkan secara deskriptif sistem pembinaan dan pengembangan koleksi pada perpustakaan STIKES Mega Reski Makassar. Jenis penelitianini adalah penelitian kualitatif deskriptif dengan pendekatan kualitatif. Pendekatan yang digunakan adalah pendekatan manajerial dan pedagogik. Sumber data dalam penelitian ini adalah Ketua STIKES, dosen, kepala perpustakaan, kepala bagian /staf, petugas perpustakaan, dan mahasiswa yang berada di STIKES Mega Reski Makassar. Data dikumpulkan dengan metode observasi, wawancara dan dokuementasi dengan instrumen utama dalam penelitian ini adalah peneliti sendiri, sedangkan instrumen sekunder adalah lembar observasi, pedoman wawancara, arsip dan dokumen, kamera, dan perekam visual. Data diolah dan dianalsisi dengan reduksi data, display data dan penarikan kesimpulan. Data diuji keabsahannya dengan menggunakan triangulasi waktu.

Hasil penelitian menunjukkan bahwa pembinaan dan pengembangan koleksi di Perpustakaan STIKES Mega Reski Makassar dilakukan dengan pengadaan koleksi bahan pustaka dalam bentuk buku di Perpustakaan STIKES Mega Reski Makassar dilakukan dengan menyediakan daftar judul buku yang hendak akan diadakan. Daftar ini pada umumnya dibuat dengan mempertimbangkan beberapa unsur yang dimulai dari intensitas penggunaanya dan keterbatasan eksemplarnya. Selain itu, penginventarisan koleksi bahan pustaka berupa buku diperpustakaan STIKES mega reski Makassar sudah berbasis Teknologi Informasi (TI) yaitu dengan melakukan pembubuhan stempel pada bagian-bagian tertentu pada buku dan selanjutnya melakukan pengimputan koleksi buku kedalam aplikasi slims yang terdapat didalam perangkat keras (komputer). Selanjutnya pemeliharaan bahan pustaka terlihat bahwa perpustakaan tidak melakukanya dalam perpustakaan melainkan membutuhkan jasa yang ada diluar perpustakaan. Alasanya karena jumlah tenaga kerja perpustakaan yang masih terbatas serta ketersediaan alat penjilidan bahan pustaka yang belum ada yang menjadi factor penghambat pemeliharaan koleksi buku perpustakaan di STIKES Mega Reski Makassar. Kemudian penyiangan yang dilakukan di Perpustakaan STIKES mega Reski Makassar didasari atas beberapa factor diantaranya koleksi yang sudah tidak terpakai lagi, dalam bahasan yang sudah tidak dikenal lagi pemustaka, bidang subjek yang sesuai untuk koleksi, jarang digunakan, serta jumlah copy yang terlalu banyak denga pengguna yang terbatas. Pelaksanaan penyiangan di Perpustakaan STIKES Mega Reski Makassar dilakukan 1 kali setahun namun terkadang juga tidak dilakukan sama sekali dalam setahun.
\end{abstract}

Keywords: Sistem Pembinaan dan Pengembangan; Koleksi Perpustakaan 


\section{PENDAHULUAN}

Setiap perpustakaan memiliki tanggung jawab dengan tuntutan profesionalisme pengelolaan, guna menjawab perkembangan zaman dan merespon serta berusaha memenuhi kebutuhan pemustaka yang selalu berkembang. Indonesia sebagai negara berkembang memiliki tanggung jawab besar dalam bidang pengembangan perpustakaan. Berbeda dengan perpustakaan negara maju pada umumnya yang telah memiliki masyarakat pengguna yang menempatkan informasi sebagai kebutuhan (needs) bukan pada keinginan (wants) sehingga kehadiran perpustakaan sangat mendapat respon yang sangat serius, baik dari kalangan pengelolah organisasi (Pustakawan), pemegang kebijakan dalam hal ini pimpinan dari lembaga dimana perpustakaan berada, sampai pada pengguna perpustakaan yang merupakan sasaran dari berdirinya sebuah perpustakaan.

Perpustakaan yang representatif, merata, dan mampu menjangkau seluruh lapisan masyarakat masih menghadapi tantangan yang tidak sederhana. Sutarno sebagaimana terkutip dalam buku organisasi informasi perpustakaan karya Wiji Suwarno mengemukakan faktor yang menyebabkan perpustakaan belum dapat berkembang dan masih belum bisa berdiri sendiri, disebabkan karena (1) Pengelolaan perpustakaan, (2) Sumber informasi, dan (3) masyarakat pemakai. ${ }^{1}$

Keberadaan perpustakaan diyakini sangat penting dalam mencerdaskan kehidupan masyarakat secara umum, sehingga pengembangannya dilakukan secara terusmenerus dengan mengacu pada visi dan misi yang dimiliki oleh perpustakaan.

Perpustakaan adalah sarana yang menjembatani antara pencipta informasi dan pencari informasi. Dengan demikian maka perpustakaan sebagai lembaga pengelola karya tulis, karya cetak, karya rekam perlu merumuskan sebuah kebijakan yang terstruktur agar mampu menciptakan pelayanan yang sesuai dengan kebutuhan pemustakanya

Setiap perpustakaan tentunya mempunyai visi yang berbeda, namun dapat dipastikan bahwa perpustakaan itu dikatakan berhasil apabila koleksi yang tersedia dapat dimanfaatkan oleh penggunanya. Salah satu aspek penting yang memberikan dampak terhadap ketertarikan masyarakat terhadap perpustakaan adalah bagaimana koleksi yang disiapkan mampu melepas dahaga akan kebutuhan informasi masyarakatnya. Perpustakaan harus membangun koleksi yang kuat guna memenuhi kebutuhan informasi pemustakanya. Dengan melihat perkembangan ilmu pengetahuan saat ini, maka untuk membentuk perpustakaan yang memiliki koleksi yang lengkap merupakan sesuatu yang mustahil apabila ditinjau dalam konteks perpustakaan yang bersifat konfensional, namun apabila tinjauan yang dilakukan dalam sudut pandang digital, itu bisa saja terjadi. Tugas dan fungsi perpustakaan yaitu menghimpun dan mengumpulkan (to colect), mengolah dan memelihara, merawat, melestarikan (to preserve), dan mengemas, dan menyajikan dan memberayakan, serta memanfaatkan dan melayankan kepada pemustaka (to available). ${ }^{2}$

Dalam pemanfaatan layanan perpustakaan, pemakai tentu memerlukan berbagai fasilitas seperti: katalog, atau basis data yang efektif, skema klasifikasi yang mudah difahami dan system sirkulasi yang efisien. Tapi itu hanyalah sarana atau sebagai media bantu pemustaka agar dapat lebih mudah mendapatkan informasi yang mereka butuhkan. Jika dilihat secara garis besar tugas pokok perpustakaan adalah melakukan pengadaan informasi, menghimpun informasi dan melayangkan informasi kepada

\footnotetext{
${ }^{1}$ Wiji Suwarno. Organisasi Informasi Perpustakaan Pendekatan Teori dan Praktik (Jakarta: Rajawali Pers, 2016), h. 7.

${ }^{2}$ Sutarno NS, Perpustakaan dan Masyarakat(Jakarta: Yayasan Obor Indonesia,2003), h. 13-14.
} 
pemustakanya. Koleksi dalam sebuah perpustakaan memegang peranan yang sangat penting, karena produk utama yang ditawarkan oleh sebuah perpustakaan adalah ketersediaan koleksi yang lengkap dalam perpustakaan. Dengan demikian, perpustakaan dituntut untuk mampu menyediakan informasi yang berkualitas dan sesuai kebutuhan pemustakanya guna memberikan pelayanan yang maksimal terhadap pemustakanya.

UU No. 43/2007 menjelaskan bahwa koleksi perpustakaan harus diseleksi, dilayankan, disimpan dan dikembangkan seusai dengan kebutuhan pemustaka dengan memperhatikan perkembangan teknologi informasi dan komunikasi, sehingga pengadaan koleksi perpustakaan harus dilakukan oleh orang-orang yang mempunyai pengetahuan luas terhadap proses pengembangan koleksi.

Pengembangan koleksi menjadi tanggung jawab pengelola perpustakaan, yang pelaksanaannya harus memperhatikan berbagai hal: (1) Kebutuhan informasi bagi pemustaka (2) Ketersediaan dana (3) Varian subjek ilmu pengetahuan (4) Jenis Koleksi (5) Jumlah Koleksi (6) Harga (7) Kualitas penerbitan dsb. Dalam konteks lebih luas, pengembangan koleksi juga melibatkan seluruh pemangku kepentingan (Stake holders), pemustaka (pemakai), pemerintah (sebagai pihak pemberi dana), masyarakat, penerbit, pemasok, dan pimpinan. ${ }^{3}$

Pertimbangan berikutnya yang memperlancar kegiatan pengembangan koleksi yaitu terkait dana yang dibutuhkan. Setiap perpustakaan apapun jenisnya atau ukuranya, harus menyisihkan sebagian dari anggaranya untuk pengembangan koleksi. Berapa persen yang disisihkan dari anggaran total untuk pengembangan koleksi.

Perpustakaan jenis apapun dikatakan memiliki koleksi sesuai dengan standar yang diterapkan dalam UU No. 43 tahun 2007 tentang perpustakaan apabila memenuhi kriteria sebagaimana yang disebutkan pada paragraf di atas.

Perpustakaan STIKES Mega Reski adalah salah satu perpustakaan perguruan tinggi yang terletak di Kota Makassar dengan memprioritaskan jenis koleksinya dalam bidang kesehatan. Jumlah koleksi berdasarkan data awal yang sudah diperoleh melalui peninjauan awal khusus untuk subyek yang berhubungan dengan kebidanan 2139 eksemplar dengan jumlah mahasiswa yang harus dilayani sebanyak 426 orang, sehingga rasio antara pengguna dengan koleksi yang tersedia berkisar 1:5. Dalam hitungan ratarata pemakaian secara keseluruhan mahasiswa kebidanan berjumlah 5 jenis judul buku perorang.

Tulisan ini akan mengungkapkan secara deskriptif sistem pembinaan dan pengembangan koleksi pada perpustakaan STIKES Mega Reski Makassar.

\section{KAJIAN TEORETIK}

Pembinaan koleksi perpustakaan meliputi kegiatan pengadaan bahan pustaka, pemberian nomor register (nomor inventaris), pemeliharaan koleksi dan penyiangan koleksi. ${ }^{4}$ Pengertian pembinaan berarti upaya untuk mengembangkan, memelihara, dan mempertahankan koleksi yang ada sebagai sumber informasi yang berguna bagi pemakai perpustakaan.

Pengembangan koleksi adalah suatu istilah yang digunakan secara luas di dunia perpustakaan untuk menyatakan bahan pustaka apa saja yang harus diadakan di perpustakaan. Pengembangan koleksi adalah semua kegiatan untuk memperluas koleksi yang ada diperpustakaan, terutama kegiatan yang berkaitan dengan pemilihan dan

${ }^{3}$ Hildawati Almah. Pemilihan dan Pengembangan Koleksi Perpustakaan. h. 5

${ }^{4}$ Noerhayati, S. Pengelolaan perpustakaan jilid II (Bandung: Alumni, 1987), h. 135. 
pengadaan bahan pustaka. ${ }^{5}$ Pengembangan koleksi lebih ditekankan pada pemilihan buku. Pemilihan buku artinya memilih buku untuk perpustakaan. Pemilihan buku berarti juga proses menolak buku tertentu untuk perpustakaan. ${ }^{6}$

Koleksi merupakan sejumlah buku atau bahan lain yang mengenai satu subjek atau merupakan satu jenis yang dihimpun oleh satu orang atau satu badan. ${ }^{7}$ Koleksi perpustakaan adalah semua informasi dalam bentuk karya tulis, karya cetak, dan/atau karya rekam dalam berbagai media yang mempunyai nilai pendidikan, yang dihimpun, diolah dan dilayangkan. ${ }^{8}$

Menurut ALA Glossary of Library and Information Science (1983) pengembangan koleksi merupakan sejumlah kegiatan yang berkaitan dengan penentuan dan koordinasi kebijakan seleksi, menilai kebutuhan pemakai, studi pemakaian koleksi, evaluasi koleksi, identifikasi kebutuhan koleksi, seleksi bahan pustaka, perencanaan kerjasama sumberdaya koleksi, pemeliharaan koleksi dan penyiangan koleksi perpustakaan. $^{9}$

Perpustakaan diharapkan dapat melayani keperluan masyarakat yang dilayaninya atau dengan sebutan pemustaka. Perpustakaan umum misalkan diharapkan dapat memenuhi kebutuhan informasi terhadap seluruh lapisan masyarakat yang menjadi target layananya. Perpustakaan khusus diharapkan bisa memenuhi kebutuhan informasi yang sangat spesifik dalam rangka menunjang visi dan misi dari lembaga induk perpustakaan khusus atau penunjang tugas pokok dari suatu instansi atau perusahaan, tempat perpustakaan berada.Perpustakaan sekolah diharapkan mampu melayani kebutuhan informasi siswa, guru dan seluruh masyarakat lingkup sekolah.Perpustakaan perguruan tinggipun diharapkan dapat memenuhi kebutuhan informasi terhadap seluruh sivitas akademika untuk menunjang tridharma perguruan tinggi yakni pendidikan dan pengajaran, penelitian dan pengabdian kepada masyarakat.

Untuk pemenuhan kebutuhan informasi oleh setiap jenis perpustakaan terhadap pemustakanya maka perpustakaan harus mengembangkan koleksinya. Secara umum koleksi perpustakaan dapat dikelompokkan sebagai berikut:

a. Koleksi yang tercetak (Printed materials)

Koleksi tercetak adalah jenis koleksi perpustakaan yang menggunakan kertas sebagai media untuk merekam informasi. Yang termasuk jenis koleksi tercetak untuk perpustakaan:

1) Buku referensi seperti ensiklopedi, kamus, biografi, indeks, abstrak, buku pedoman, buku tahunan, direktori.

2) Buku teks untuk pelajar dan mahasiswa

3) Majalah ilmiah

4) Majalah popular seperti Gatra dan Tempoo

5) Buku fiksi

6) Buku-buku umum seperti buku keagamaan, social, dan kemasyarakatan

7) Laporan penelitian

8) Buku-buku pengetahuan social dan kemasyarakatan

${ }^{5}$ F. Rahayuningsih. Pengelolaan Bahan Pustaka(Yogyakarta: Graha ilmu, 2007), h. 13.

${ }^{6}$ Sulistio-Basuki. Pengantar Ilmu Perpustakaan (Jakarta: Gramedia. Pustaka Utama, 1991), h. 427

${ }^{7}$ Sutarno NS. Kamus Perpustakaan dan Informasi (Jakarta: Jala, 2008). h. 105

${ }^{8}$ Perpustakaan Nasional. 2009. Undang-Undang Ri Nomor 43 Tahun 2007 Tentang Perpustakaan (Jakarta: CV. Tamita Utama). h. 5

${ }^{9}$ Ade Kohar. Teknik Kebijakan Pengembangan Koleksi (Jakarta: Perpustakaan, 2013), h. 12. 
9) Karya ilmiah (skripsi, tesis dan disertasi) ${ }^{1}$

0

Ada empat jenis koleksi perpustakaan yaitu

a. Karya cetak

Karya cetak adalah hasil pemikiran manusia yang dituangkan dalam bentuk cetak, seperti:

1) Buku

Buku adalah bahan pustaka yang merupakan suatu kesatuan utuh dan yang paling utama terdapat dalam koleksi perpustakaan. Berdasarkan standar dari Unesco tebal buku paling sedikit 49 halaman tidak termasuk kulit maupun jaket buku. Diantaranya buku fiksi, buku teks, dan buku rujukan.

2) Terbitan berseri

Bahan pustaka yang direncanakan untuk diterbitkan terus dengan jangka waktu terbit tertentu. Yang termasuk dalam bahan pustaka ini adalah harian (surat kabar), majalah (mingguan bulanan dan lainnya), laporan yang terbit dalam jangka waktu tertentu, seperti laporan tahunan, tri wulanan, dan sebagainya.

3) Bahan Grafika

Ada dua tipe bahan grafika yaitu bahan pustaka yang dapat dilihat langsung (misalnya lukisan, bagan, foto, gambar, teknik dan sebagainya) dan yang harus dilihat dengan bantuan alat (misalnya selid, transparansi, dan filmstrip).

a) Bahan Kartografi Yang termasuk kedalam jenis ini adalah peta, atlas, bola dunia, foto udara, dan sebagainya.

b) Bentuk mikro adalah suatu istilah yang digunakan untuk menunjukkan semua bahan pustaka yang menggunakan media film dan tidak dapat dibaca dengan mata biasa melainkan harus memakai alat yang dinamakan microreader. Bahan pustaka ini digolongkan tersendiri, tidak dimasukkan bahan noncetak.

Hal ini disebabkan informasi yang tercakup didalamnya meliputi bahan tercetak seperti majalah, surat kabar, dan sebagainya. Ada tiga macam bentuk mikro yang sering menjadi koleksi perpustakaan yaitu:

a) Mikrofilm, bentuk mikro dalam gulungan film. Ada beberapa ukuran film yaitu $16 \mathrm{~mm}$, dan $35 \mathrm{~mm}$.

b) Mikrofis, bentuk mikro dalam lembaran film dengan ukuran $105 \mathrm{~mm} \mathrm{x}$ $148 \mathrm{~mm}$ (standar) dan $75 \mathrm{~mm} \times 125 \mathrm{~mm}$.

c) Microopaque, bentuk mikro dimana informasinya dicetak kedalam kertas yang mengkilat tidak tembus cahaya. Ukuran sebesar mikrofis.

d. Koleksi yang terekam (bahan audio visual)

Koleksi terekam adalah bahan koleksi perpustakaan yang menggunakan pita, disc dan sejenis untuk merekam informasi. yang termaksud jenis koleksi ini adalah

1) Kaset seperti kaset untuk lagu-lagu daerah, ceramah keagamaan, pidato penting

2) Video misalnya video kegiatan lembaga induk perpustakaan, video rekaman peristiwa-peristiwa penting.

Karya noncetak adalah hasil pemikiran manusia yang dituangkan tidak dalam bentuk cetak seperti buku atau majalah, melainkan dalam bentuk

\footnotetext{
${ }^{1}$ Hartono.Manajemen Perpustakaan Sekolah (Yogyakarta: Ar-Ruzz Media, 2016), h 168.
} 
lain seperti rekaman suara, rekaman video, rekaman gambar dan sebagainya. Istilah lain yang dipakai untuk bahan pustaka acheter viagra ini adalah bahan non buku, ataupun bahan pandang dengar. Yang termasuk dalam jenis bahan pustaka ini adalah:

\section{1) Rekaman suara}

Yaitu bahan pustaka dalam bentuk pita kaset dan piringan hitam. Sebagai contoh untuk koleksi perpustakaan adalah buku pelajaran bahasa inggris yang dikombinasikan dengan pita kaset.

2) Gambar hidup dan rekaman video

Yang termasuk dalam bentuk ini adalah film dan kaset video. Kegunaannya selain bersifat rekreasi juga dipakai untuk pendidikan. Misalnya untuk pendidikan pemakai, dalam hal ini bagimana cara menggunakan perpustakaan. ${ }^{1}$

e. Koleksi digital

Dengan adanya teknologi informasi, maka infornasi dapat dituangkan ke dalam media elektronik seperti pita magnetis dan cakram atau disc.Untuk membacanya diperlukan perangkat keras seperti computer, CD-ROM player, dan sebagainya. ${ }^{1}$

Dengan adanya teknologi informasi, maka informasi, maka informasi dapat dituangkan kedalam media elektronik seperti pita magnetic dan cakram atau disc. Untuk membcanya diperlukan perangkat keras seperti komputer, CD-ROM (compact disc read only memory) player dan sebagainya. Media CD-ROM termasuk ke dalam jenis media digital dan optical discs. Optical discs ialah media yang dibuat dengan proses scanning pada sumber asli, kemudian dibuatkan semacam lubang-lubang pada pita magnetic yang dapat dibaca oleh sinar laser sehingga menghasilkan gambar dimonitor komputer. Setiap lembar CD-ROM mampu menyimpan banyak data, baik data gambar maupun data teks. Media ini hanya dapat oleh pemustaka tanpa bisa merubah isinya. Instrumen yang digunakan untuk mengakses CD-ROM adalah komputer multimedia. Cara pemakaiannya yang cukup mudah membuat media ini banyak disenangi.Selain itu memiliki sistem kerja dan kecepatan akses yang dapat diandalkan. Padasaat ini CD-ROM telah umum dipakai diperpustakaan riset dan perpustakaan perguruan tinggi. ${ }^{1}$

\section{METODOLOGI PENELITIAN}

Jenis penelitianini adalah penelitian kualitatif deskriptif dengan pendekatan kualitatif. Pendekatan yang digunakan adalah pendekatan manajerial dan pedagogik. Sumber data dalam penelitian ini adalah Ketua STIKES, dosen, kepala perpustakaan, kepala bagian /staf, petugas perpustakaan, dan mahasiswa yang berada di STIKES Mega Reski Makassar. Data dikumpulkan dengan metode observasi, wawancara dan dokuementasi dengan instrumen utama dalam penelitian ini adalah peneliti sendiri, sedangkan instrumen sekunder adalah lembar observasi, pedoman wawancara, arsip dan dokumen, kamera, dan perekam visual. Data diolah dan dianalsisi dengan reduksi data, display data dan penarikan kesimpulan. Data diuji keabsahannya dengan menggunakan triangulasi waktu.

\footnotetext{
${ }^{1}$ Andi Ibrahim. Pengantar Ilmu Perpustakaan dan Kearsipan, h. 186-187.

${ }^{1}$ Yuyu Yulia. Kebijakan Pengémbangan Koleksi Perpustakaan (Jakarta: Perpustakaan Nasionala RI, 1993), h. 3.

${ }^{1}$ Sulistyo-Basuki.Pengantar I mu Perpustakaan (Jakarta: Gramedia, 1999), h. 88.
} 


\section{HASIL PENELITIAN DAN PEMBAHASAN}

\section{A. Sistem Pembinaan Koleksi Buku di Pepustakaan STIKES Mega Reski Makassar}

Perpustakaan adalah lembaga yang menjadi perantara pencipta informasi dan penikmat informasi, dan terkadang perpustakaan juga disebut sebagai pencipta informasi. Perkembangan zaman memberikan tuntutan kepada setiap lembaga untuk mampu berselancar dalam derasnya ombak pengetahuan yang mengalir begitu cepat. Hal ini yang kemudian menjadi salah satu faktor yang menyebabkan antusias yang tinggi oleh setiap lembaga untuk beradaptasi terhadap perkembangan yang ada tidak terkecuali perpustakaan.

Sebagai lembaga yang mengelola sumber daya informasi, perpustakaan dituntut untuk tidak hanya melihat sesuatu dalam sudut pandang yang sempit, melainkan harus penuh perencanaan yang matang sehingga tidak menimbulkan kesalahan dalam pelaksanaan kegiatan yang berhubungan dengan perpustakaan. Koleksi buku yang terdapat dalam perpustakaan merupakan sumber daya informasi yang memberikan pengaruh yang cukup besar terhadap minat kunjung penggunanya. Dengan demikian, perpustakaan harus mampu merumuskan sebuah kebijakan untuk bisa menyediakan koleksi buku yang bisa memenuhi kebutuhan masyarakat yang akan dilayaninya. Dalam hal ini pustakawan dituntut untuk mempunyai kesadaran agar pembinaan koleksi.

Proses yang akan dilakukan dalam merumuskan kebijakan dalam pembinaan koleksi perpustakaan yaitu dimulai dari pengadaan koleksi, registrasi koleksi, pemeliharaan koleksi, dan penyiangan koleksi.

Perpustakaan STIKES Mega Reski Makassar mempunyai tanggung jawab yang cukup besar. Sebagai lembaga yang berada di dalam naungan sekolah tinggi ilmu kesehatan, sangat dituntut untuk menyediakan informasi yang sesuai dengan kebutuhan masyarakat yang dilayaninya. Mengingat alumni-alumni yang nantinya akan masuk dalam dunia kerja dan tentunya akan bersentuhan langsung dengan kehidupan yang real, terlebih dahulu harus dibekali dengan pemahaman terhadap teori-teori memadai. Bekal pengetahuan yang diberikan oleh tenaga pengajar (dosen) hanyalah sekian persen dari teori pengetahuan yang ada dipenjuru dunia. Oleh karena itu pengelolah informasilah yang menjadi sarana strategis untuk dimanfaatkan dalam mengembangkan pengetahuan terhadap teori yang dibutuhkan, dalam hal ini adalah perpustakaan.

a. Pengadaan Koleksi Buku di perpustakaan STIKES Mega Reski Makassar

Untuk mengetahui bagaimana sistem pengadaan koleksi buku yang ada di Perpustakaan STIKES Mega Reski Makassar, maka dilakukan wawancara dengan hasil sebagai berikut, Ma'shum, S.IP sebagai Kepala Perpustakaan STIKES Mega Reski Makassar mengatakan bahwa subjek koleksi buku yang tersedia di perpustakaan sudah sesuai dengan kebutuhan mahasiswa sekaligus staf pengajar di STIKES Mega Reski Makassar. Hal ini terjadi karena adanya kesadaran pihak perpustakaan untuk melakukan sebuah tinjauan awal sebelum melakukan pengadaan bahan pustaka. ${ }^{1}$

${ }^{1}$ Ma'shum, Kepala Perpustakaan Stikes Mega reski Makassar, Wawancara, Makassar, 24 Februari 2017. 
Hal senada juga diungkapkan oleh Khoeruddin bahwa setiap pengadaan bahan pustaka di Perpustakaan STIKES mega reski Makassar pada dasarnya dimulai dari penyediaan daftar list koleksi yang akan diadakan. ${ }^{1}$

Zukmawaty mengatakan bahwa koleksi yang akan dikembangkan pada umumnya bersumber dari mahasiswa, namun ada beberapa jurusan seperti D-IV kebidanan itu terlebih dahulu dikumpulkan uang sumbangan bukunya ke akademik lalu pihak akademik meminta pihak perpustakaan untuk membuat daftar judul buku yang diperlukan oleh perpustakaan. ${ }^{1}$

Dari hasil wawancara yang dilakukan tersebut dapat disimpulkan bahwa pengadaan koleksi bahan pustaka dalam bentuk buku di Perpustakaan STIKES Mega Reski Makassar dilakukan dengan menyediakan daftar judul buku yang hendak akan diadakan. Daftar ini pada umumnya dibuat dengan mempertimbangkan beberapa unsur yang dimulai dari intensitas penggunaanya dan keterbatasan eksemplarnya.

\section{b. Registrasi Koleksi Buku}

Kegiatan infentaris adalah memeriksa, memberi stempel, dan mencatat/menftar semua koleksi perpustakaan dalam buku induk dan diberi nomor induk setiap satu eksemplar. ${ }^{1}$

Untuk mengetahui bagaimana sitem intevantaris koleksi buku di Perpustakaan STIKES Mega Reski Makassar, maka dilakukan wawancara dengan hasil sebagai berikut, Ma'shum Kepala Perpustakaan STIKES Mega Reski Makassar mengatakan bahwa setiap koleksi yang masuk diperpustakaan perlu di inventaris, hal ini dilakukan agar memudahkan pengelolah perpustakaan untuk membuat laporan terhadap profil koleksi perpustakaan. Pelaksanaan inventaris yang kami lakukan papasnya yaitu memberikan stempel pada setiap koleksi buku yang baru diadakan. Tahap selanjutnya yaitu dengan mengimput seluruh koleksinya kedalam aplikasi perpustakaan kami (SLIMS) dan secara otomatis koleksi yang baru masuk terimput dan terinventaris. ${ }^{1}$

Zukmawaty mengatakan bahwa koleksi yang baru masuk keperpustakaan tidak serta merta langsung disusn kedalam rak, melainkan ada beberapa tahapan yang kami lakukan.Tahapan itu yaitu pemberian stempel yang dilakukan oleh ibu Nur dan selanjutnya diserahkan kepada kepala perpustakaan (Ma'shum) untuk diimput kedalam computer perpustakaan. ${ }^{1}$

Nur selaku staf perpustakaan juga menegaskan bahwa apa yang diungkapkan oleh Zukmawaty benar adanya, dimana tugas yang memang selalu dia lakukan ketika koleksi buku baru masuk yaitu dengan membubuhkan stempel pada bagian-bagian buku baru. $^{2}$

Berdasarkan hasil wawancara yang dilakukan jelas tergambar bahwa penginventarisan koleksi bahan pustaka berupa buku diperpustakaan STIKES Mega Reski Makassar sudah berbasis Teknologi Informasi (TI) yaitu dengan melakukan pembubuhan stempel pada bagian-bagian tertentu pada buku dan selanjutnya melakukan

\footnotetext{
${ }^{1}$ Khoeruddin. Waka II Bidang ${ }^{5}$ Administrasi Umum dan Keuangan Stikes Mega Reski Makassar, Wawancara, 26 Februari 2017

${ }^{1}$ Zukmawaty, S.Sos, Pegawai Perpustakaan Stikes Mega Reski Makassar, Wawancara, Makassar, 24 Hebruari 2017.

${ }^{1}$ Hartono. Manajemen Perpustakaan Sekolah (AR-RUZZ Media: Yogyakarta, 2016), h. 75.

${ }^{1}$ Ma'shum, Kepala Perpustak̊aan Stikes Mega reski Makassar, Wawancara, Makassar, 24 Februari 2017.

${ }^{1}$ Zukmawaty, S.Sos, Pegawai Perpustakaan Stikes Mega Reski Makassar, Wawancara, Makassar, 24 Hebruari 2017.

${ }^{2}$ Nur. Staf Perpustakaan Stikes Mega Reski Makassar, Wawancara, Makassar, 24 Februari 2017
} 
pengimputan koleksi buku kedalam aplikasi slims yang terdapat didalam perangkat keras (Computer).

\section{c. Pemeliharaan bahan pustaka}

Pemeliharaan bahan pustaka tidak hanya menyangkut pelestarian dalam bentuk fisik, tetapi juga pelestarian dalam bidang informasi yang terkandung di dalamnya.

Untuk mengetahui bagaimana sistem pemeliharaan bahan pustaka di Perpustakaan STIKES mega Reski Makassar dapat dilihat dari beberapa pernyataan dari informan berikut, Ma'shum mengatakan bahwa pihak perpustakaan tidak pernah melakukan penjilidan koleksi, namun dia menegaskan bahwa perpustakaan pernah beberapa kali membawa koleksinya kepercetakan untuk dijilid apabila ada koleksi yang masih sangat dibutuhkan namun nilai informasi serta fisik buku sudah memprihatinkan (rusak). Alasan kami mengapa tidak melakukan penjilidan sendiri karena yang pertama, kami hanya terdiri dari 4 anggota yang jelas tugasnya sangat banyak jika dilihat dari jumlah pengguna perpustakaan yang harus dilayani, dan kedua, perpustakaan memang belum mempunyai peralatan yang memadai untuk melakukan penjilidan koleksi. ${ }^{2}$

Dwi Nining Apriliani, mahasiswa S-I Farmasi yang juga salah seorang anggota perpustakaan STIKES mega reski Makassar ketika melakukan wawancara, mengatakan bahwa koleksi perpustakaan STIKES mega reski Makassar sudah tergolong tua, dimana pada beberapa kesempatan dia (Dwi) menemukan beberapa buku yang berhubungan dengan topic tugas yang dia cari sudah tidak ada, serta ada beberapa buku yang sangat sering digunakan teman-temanya serta dia (Dwi) sampulnya sudah robek. ${ }^{2}$

Nur, Staf Perpustakaan STIKES Mega Reski Makassar menjelaskan bahwa pihaknya tidak pernah melakukan penjilidan koleksi bahan pustaka meskipunbukunya sudah rusak.Seingatnya bahwa pernah koleksi bahan pustaka diperbaiki oleh sekuriti namun tidak dengan menjilid, melainkan dipaku saja. ${ }^{2}$

Dengan demikian, maka hasil wawancara terhadap pemeliharaan bahan pustaka terlihat bahwa perpustakaan tidak melakukanya dalam perpustakaan melainkan membutuhkan jasa yang ada diluar perpustakaan. Alasanya karena jumlah tenaga kerja perpustakaan yang masih terbatas serta ketersediaan alat penjilidan bahan pustaka yang belum ada yang menjadi factor penghambat pemeliharaan koleksi buku perpustakaan di STIKES Mega Reski Makassar.

\section{d. Penyiangan}

Penyiangan merupakan salah satu langkah dalam pengembangan koleksi yang sulit untuk dilakukan, tetapi langkah ini merupakan sesuatu proses yang tidak cukup kala penting. Sebuah perpustakaan tanpa melakukan penyiangan, maka koleksinya tidak akan mutakhir.

Untuk mengetahui bagaimana penyiangan yang terjadi diperpustakaan STIKES Mega Reski Makassar, dapat dilihat dari hasil wawancara berikut, Ma'shum menyatakan bahwa perpustakaan melakukan penyiangan sekali setahun dan terkadang juga tidak sama sekali. Kriteria yang menjadi alasan untuk menyiangi koleksinya ada beberapa diantaranya: tidak terpakai lagi karena kadarluasa, dalam bahasan yang kurang mengena

\footnotetext{
${ }^{2}$ Ma'shum, Kepala Perpustakaan Stikes Mega reski Makassar, Wawancara, Makassar, 24 Februari 2017.

${ }^{2}$ Dwi Nining Apriliani, mahasi̊swa S-I Farmasi, Wawancara, Makassar, 26 Februari 2017

${ }^{2}$ Nur. Staf Perpustakaan Stikes Mega Reski Makassar, Wawancara, Makassar, 24 Februari 2017.
} 
terhadap kebutuhan pemustaka, jarang dipakai, serta jumlah copy yang tidak sesuai dengan permintaan. ${ }^{2}$

Zukmawaty.Pustakawan STIKES Mega Reski Makassar mengatakan bahwa perpustakaan pelakukan kegiatan penyiangan 1 kali dalam setahun, namun terkadang hal ini tidak dilakukan mengingat kegiatan ini pada umumnya mengganggu kenyamanan pemustakanya.Kriteria yang digunakan dalam menyiangi bahan pustaka dia (Zukmawati) menjelaskna bahwa ketika koleksi itu tidak terpakai lagi maka harus disiangi, lalu kemudian alasan selanjutnya yaitu bahan subjek yang kurang sesuai untuk koleksi maka harus disiangi. ${ }^{2}$

Fathoanah Qiran Sakinah, salah seorang mahasiswi S-I Farmasi STIKES Mega Reski Makassar menjelaskan bahwa koleksi Perpustakaan STIKES Mega Reski Makassar menurutnya ada yang jumlah koleksi yang dalam judul yang sama sangat banyak namun kurang digunakan, da nada juga koleksi buku yang dalam satu judul hanya beberapa copy saja tetapi banyak penggunanya. Dia (Fathoanah Qiran Sakinah) memberikan contoh buku metodologi penelitian. ${ }^{2}$

Dengan demikian, maka hasil wawancara yang penulis lakukan menjelaskan bahwa penyiangan yang dilakukan di Perpustakaan STIKES mega Reski Makassar didasari atas beberapa factor diantaranya koleksi yang sudah tidak terpakai lagi, dalam bahasan yang sudah tidak dikenal lagi pemustaka, bidang subjek yang sesuai untuk koleksi, jarang digunakan, serta jumlah copy yang terlalu banyak denga pengguna yang terbatas. Pelaksanaan penyiangan di Perpustakaan STIKES Mega Reski Makassar dilakukan 1 kali setahun namun terkadang juga tidak dilakukan sama sekali dalam setahun.

\section{B. Sistem Pengembangan Koleksi di Perpustakaan STIKES Mega Rezky Makassar}

Berdasarkan penelitian yang penulis lakukan terhadap sistem pengembangan koleksi di Perpustakaan STIKES Mega Rezky Makassar yang terjadi pada tanggal 24 dan 25 Februari 2017 memberikan gambaran sebagai berikut,

\section{Analisis Kebutuhan Pemustaka}

Dalam kegiatan pengembangan koleksi perpustakaan, analisis kebutuhan pemustaka sangat penting dilakukan agar dalam pengadaan koleksi sesuai dengan kebutuhan pemakai jasa informasi atau civitas akademika. Mengenali kebutuhan pemakai/civitas akademika sangat penting sebelum pengembangan koleksi dilakukan.

Berdasarkan hasil wawancara dengan Ma'shum, Kepala Perpustakaan STIKES Mega Reski Makassar menegaskan bahwa untuk memenuhi kebutuhan pemustaka pihak Perpustakaan STIKES Mega Rezky Makassar mengkaji informasi apa yang dibutuhkan dengan cara memberikan kesempatan kepada pemustaka untuk mengusulkan koleksi atau informasi yang diperlukan. Selanjutnya pihak perpustakaan yang menyeleksi koleksi dengan melakukan beberapa pertimbangan baik dari segi harga, ketersediaan koleksi dan

${ }^{2}$ Ma'shum, Kepala Perpustakaan Stikes Mega reski Makassar, Wawancara, Makassar, 24 Februari 2017.

2 Zukmawaty, S.Sos, Pegawai Perpustakaan Stikes Mega Reski Makassar, Wawancara, Makassar, 24 Hebruari 2017.

${ }^{2}$ Fathoanah Qiran Sakinah, Mahasiswi S-I Farmasi Stikes Mega Reski Makassar, Wawancara, Makassar, 26 Februari 2017 
menyangkut muatan informasi koleksi tersebut.Cara ini sangat efektif untuk mengenali kebutuhan pemustaka. ${ }^{2}$

Zukmawaty, Pegawai bagian pengolahan di Perpustakaan STIKES Mega Rezky Makassar bahwa dalam kegiatan pengembangan koleksi harus relevan dengan kebutuhan pemustaka. Mengingat hal ini pihak perpustakaan bersurat ke fakultas untuk mengetahui koleksi apa yang dibutuhkan. ${ }^{2}$

Pendapat di atas tidak jauh berbeda dengan pendapat pegawai di bagian sirkulasi (Nur Hadrimiyati) bahwa untuk mengenali kebutuhan pemakai perlu dilakukan pengkajian seperti suvey kebutuhan pemakai agar pengembangan koleksi sesuai dengan kebutuhan informasi pemustaka. ${ }^{2}$

Berdasarkan beberapa jawaban dari informan maka dapat diuraikan bahwa untuk mengenali kebutuhan pemustaka di Perpustakaan STIKES Mega Rezky Makassar maka dilakukakn beberapa cara, yaitu:

a) Melakukan survey terhadap pengguna perpustakaan

b) Mengirimkan formulir isian pengadaan koleksi kepada Prodi yang ada di Fakultas.

c) Memberi kesempatan kepada pemustaka (mahasiswa, dosen, dan staff) untuk mengusulkan koleksi yang perlu dibutuhkan.

\section{Kebijakan Seleksi}

Dalam kegiatan pengembangan koleksi perpustakaan kebijakan seleksi sangat diperlukan mengingat beragamnya kebutuhan pemustaka akan informasi. Dalam kegiatan kebijakan seleksi memuat tentang pelaksanaan seleksi, alat bantu seleksi dan koleksi apa yang akan dijadikan koleksi perpustakaan. Kebijakan seleksi bertujuan untuk meminimalisir kebutuhan informasi pemustaka.

Dalam kebijakan seleksi bidang perencanaan dan pengembagan koleksi membentuk tim seleksi (selektor) yang beranggotakan 4 (empat) orang yang dipimpin langsung oleh kepala perpustakaan. Ini dibentuk berdasarkan intruksi Kepala Perpustakaan STIKES Mega Rezky makassar. Para selektor mengkaji daftar usulan koleksi bahan pustaka yang diusulkan oleh program studi ditiap fakultas, dosen, staff dan mahasiswa. Setelah diperoleh keputusan koleksi apa yang perlu diadakan maka selanjutnya dibuatlah daftar usulan koleksi. ${ }^{3}$

Khoeruddin, wakil ketua II bidang administrasi dan keuangan STIKES Mega Reski Makassar juga mengatakan bahwa perpustakaan dihimbau untuk melakukan penilaian terhadap koleksi apa yang akan diadakan ketika hendak ingin membeli buku yang bersumber dari alumni, lalu selanjutnya pihak jurusan yang melakukan pembelian ke toko buku atau ke penerbit. ${ }^{3}$

Dari hasil wawancara tersebut, secara tegas menjelaskan bahwa dalam merumuskan kebijakan pengembangan koleksi perpustakaan terlebih dahulu dilakukan:

${ }^{2}$ Ma'shum, Kepala Perpustakaan Stikes Mega Reski Makassar, Wawancara, Makasar, 24 Februari 2017

2 Zukmawaty, S.Sos, Pegawai Perpustakaan Stikes Mega Reski Makassar, Wawancara, Makassar, 24 Hebruari 2017.

${ }^{2}$ Nur. Staf Perpustakaan Stikes Mega Reski Makassar, Wawancara, Makassar, 24 Februari 2017. februari 2017.

${ }^{3}$ Mashum, S.IP, Kepala Perpustakaan Stikes Mega Reski Makassar, Wawancara, Makassar, 24

${ }^{3}$ Khoeruddin, Wakil Ketua II ${ }^{1}$ Bidang Administrasi Umum dan Keuangan Stikes Mega Reski Makassar, Makassar, Wawancara, 25 Februari 2017 
a) Pembentukan tim seleksi

b) Para selektor mengkaji daftar usulan koleksi bahan pustaka yang diusulkan oleh program studi di setiap fakultas

c) Kajian ketersiadaan koleksi yang ada

d) Setelah diperoleh keputusan koleksi apa yang perlu diadakan maka selanjutnya dibuatlah daftar usulan koleksi.

\section{Proses Seleksi}

Seleksi bahan pustaka (koleksi) merupakan kegiatan penting yang perlu dilakukan oleh perpustakaan karena ini sangat berkaitan dengan kualitas koleksi yang ada. Apabila koleksi perpustakaan tidak sesuai dengan kebutuhan informasi pemustakanya maka keberadaan perpustakaan itu tidak ada artinya karena pada prinsipnya keberadaan sebuah perpustakaan untuk membantu memenuhi kebutuhan informasi pemustakanya.

Dalam menyeleksi bahan pustaka (koleksi) memerlukan keterampilan (skill) dan pengetahuan (knowledge) yang mendalam agar dalam penyeleksian koleksi benarbenar berorientasi kepada pemustaka. Kegiatan seleksi dilakukan untuk meminimalisir kebutuhan pemustaka.

Berdasarkan hasil wawancara dengan Kepala Perpustakaan STIKES Mega Rezky Makassar bahwa proses seleksi terus dilakukan tanpa menunggu persetujuan adanya anggaran pembelian atau tidak. Data hasil seleksi disimpan sampai pada waktunya di siapkan untuk pembelian. Pada tahap ini harus di perhatikan buku teks, buku sesuai dengan mata kuliah yand disini, Informasi kepengarangan, edisi dan terbitan antara 2011 sampai sekarang, ada nomor ISBN, Harga itu buku serta penerbit juga menjadi salah satu pertimbangan kami. $^{3}$

Zukmawati, pustakawan STIKES mega reski Makassar juga mengatakan bahwa kebijakan dalam mengembangkan koleksi perlu dituangkan dalam bentuk tertulis. Dia (Zukmawati) juga menegaskan bahwa koleksi yang intensitas pemakainya cukup tinggi, maka perlu dilakukan penambahan koleksi.

Adapun uraian seleksi bahan pustaka yang dilakukan oleh Perpustakaan STIKES Mega Rezky Makassar yaitu sebagai berikut:
a) Merupakan buku teks
b) Buku sesuai dengan mata kuliah pada Prodi di lingkungan STIKES Mega Rezky Makassar;
c) Informasi kepengarangan
d) Merupakan edisi dan terbitan terbaru
e) Mencantumkan Nomor ISBN
f) Harga buku
g) Penerbit
h) Intensitas pemakaian koleksi yang ada

\section{Proses Pengadaan}

Pengadaan bahan pustaka adalah taham yang dilakukan ketika analisis kebutuhan telah dilakukan. Biasanya tahap ini dilakukan ketika kebijakan pengembangan koleksi sudah dirumuskan dalam bentuk tertulis. Ada beberapa cara yang dilakukan oleh perpustakaan ketika hendak melakukan pengadaan. Proses ini umunya sangat berlaku

${ }^{3}$ Mashum, S.IP, Kepala Perpůstakaan Stikes Mega Reski Makassar, Wawancara, Makassar, 24 februari 2017. 
pada setiap perpustakaan yakni pembelian, tukar menukar, hadiah, dan sumbangan wajib. ${ }^{3}$

Berdasarkan dari hasil wawancara yang dilakukan peneliti dijelaskn bahwa pengadaan koleksi buku di Perpustakaan STIKES Mega Reski Makassar dilakukan dengan beberapa cara yaitu:

a. Sumbangan

Layaknya perpustakaan perguruan tinggi lainya, Perpustakaan STIKES Mega Reski Makassar meminta sumbangan dari mahasiswa diakhir studinya. Pengadaan koleksi dengan cara ini sangat membantu perpustakaan untuk bisa menyediakan informasi sesuai dengan kebutuhan pemustakanya. Wisudawan ketika hendak menerima ijazah, maka terlebihdahulu mengurus bebas pustaka. Proses inilah yang selanjutnya dimanfaatkan perpustakaan untuk merekomendasikan mahasiswa agar membeli koleksi buku yang sudah masuk dalam list atau daftar koleksi yang akan diadakan.Perpustakaan juga pernah sekali menerima sumbangan koleksi buku dari Dinas Perpustakaan Kota Makassar. $^{3}$

Mutmainnah, dosen analis kesehatan di STIKES mega reski Makassar juga mengatakan bahwa perpustakaan menerima sumbangan koleksi buku dari alumni sebanyak dua kali dalam setahun. ${ }^{3}$ Hal ini juga dipertegas dengan Julian Fitrianingsih, Dosen sekaligus Wakil Ketua I di STIKES Mega Reski Makassar mengatakan bahwa mahasiswa yang wisuda pada setiap tahunya terjadi sebanyak dua kali dalam setahun. ${ }^{3}$

Berdasarkan hasil wawancara tersebut, perpustakaan menerima sumbangan berupa koleksi buku yang bersumber dari alumni dan Dinas Perpustakaan Kota Makassar.

b. Pembelian

Pengadaan koleksi yang baik tentunya diperoleh melalui pengadaan dengan cara pembelian. Melalui cara pembelian, perpustakaan bisa secara bebas memilih koleksi apa yang betul-betul sesuai dengan apa yang menjadi kebutuhan perpustakaan. Pengadaan dengan cara pembelian, perpustakaan bisa menentukan kualitas isi dan fisik buku sesuai dengan keinginan.

Ma'shum, Kepala Perpustakaan STIKES Mega Reski Makassar menjelaskan bahwa pembelian koleksi buku pada tahun 2017 belum dilakukan, hal ini dikarenakan belum tersedianya dana untuk itu. Namun ditahun 2016 perpustakaan pernah melakukan pembelian buku yang bersumber dari dana yang terkumpul dari pembuatan kartu mahasiswa. Pembelian langsung kepenerbit jauh lebih murah dibandingkan membeli di took buku, hal ini dikarenakan took buku sudah dikenakan PPN sehingga secara otomatis harga bukunya juga lebih mahal. ${ }^{3}$

Zukmawaty juga menjelaskan bahwa keuntungan yang diperoleh ketika membeli buku langsung ke penerbit adalah pemesanan bisa langsung melalui fia Email.

${ }^{3}$ Hildawati Almah. Pemilihan ${ }^{3}$ dan Pengembangan Koleksi Perpustakaan (Makassar: Alauddin Press, 2012), h. 79-81.

${ }^{3}$ Mashum, S.IP, Kepala Perpưstakaan Stikes Mega Reski Makassar, Wawancara, Makassar, 24 februari 2017.

${ }^{3}$ Mutmainnah.Dosen Analis Kesehatan Stikes Mega Reski Makassar.Wawancara, Makassar, 26 Februari 2017

${ }^{3}$ Julia Fitrianingsih. Wakil Kétua I Stikes Mega Reski Makassar, Wawancara, Makassar, 26 Februari 2017

${ }^{3}$ Mashum, S.IP, Kepala Perpu'stakaan Stikes Mega Reski Makassar, Wawancara, Makassar, 24 februari 2017. 
Jadi tidak perlu repot pergi ketempatnya karena barang bisa langsung diantarkan keperpustakaan. $^{3}$

Berdasarkan dari hasil wawancara tersebut, maka terlihat bahwa perpustakaan di tahun 2017 belum melakukan pengadaan koleksi buku melalui pembelian. Perpustakaan STIKES Mega Reski Makassar Membeli buku di tahun 2016 dengan dana yang diperoleh dari uang pembuatan kartu mahasiswa. Pembelian langsung kepenerbit jauh lebih menguntungkan dibandingkan langsung membeli ke took buku.

c. Titipan

Titipan adalah koleksi yang berasal dari perorangan atau lembaga yang menitipkan koleksinya pada perpustakaan. Perolehan koleksi terjadi tanpa terencana sehingga perlu penyeleksian yang benar. Pihak perpustakaan harus memperhatikan sumber titipan, sebab koleksi yang tidak sesuai kebutuhan pada akhirnya hanya akan menambah biaya operasional perawatan koleksi dan juga mengurangi produktifitas waktu yang digunakan oleh pustakawan.

Ma'shum menjelaskna bahwa Perpustakaan STIKES mega reski Makassar sejak tahun 2010 sudah tidak mendapatkan titipan dari manapun. ${ }^{3}$ Hal senada juga disampåkan oleh Zukmawati, ketika ditanya dari mana saja perpustakaan mendapatkan titipan koleksi buku, dia (Zukmawati) mengatakan bahwa tidak ada buku titipan di Perpustakaan STIKES Mega Reski Makassar. ${ }^{4}$

d. Tukar Menukar

Pengadaan bahan pustaka dengan cara ini dilakukan secara terencana, karena biasanya pertukaran dilakukan berdasarkan kerja sama antar perpustakaan. Pertukaran dapat dilakukan apabila jumlah eksemplar terlalu banyak dan apabila ada sejumlah koleksi yang tidak dapat diperlukan lagi, namun diperlukan oleh perpustakaan lain.

Hasil wawancara yang dilakukan, menjelaskan bahwa pengadaan bahan pustaka diSTIKES Mega Reski Makassar dengan cara tukar menukar dapat diketahui dari hasil wawancara berikut: Ma'shum, ketika di berikan apakah perpustakaan pernah melakukan kerja sama dalam hal tukar menukar koleksi bahan pustaka, dia menjelaskan bahwa sejauh ini perpustakaan hanya memberikan pinjaman kebeberapa perpustakaan perguruan tinggi yang meminta untuk dipinjamkan, namun untuk kerja sama silang koleksi sejauh ini belum dilakukan. ${ }^{4}$

Berdasarkan hasil wawancara tersebut dijelaskan bahwa perpustakaan STIKES Mega Reski Makassar tidak melakukan kerja sama dalam hal tukar menukar koleksi buku.

\section{PENUTUP}

Berdasarkan uraian di atas maka dapat disimpulkan bahwa pembinaan dan pengembangan koleksi di Perpustakaan STIKES Mega Reski Makassar dilakukan dengan pengadaan koleksi bahan pustaka dalam bentuk buku di Perpustakaan STIKES Mega Reski Makassar dilakukan dengan menyediakan daftar judul buku yang hendak akan

${ }^{3}$ Zukmawaty, S.Sos, Pegawai Perpustakaan Stikes Mega Reski Makassar, Wawancara, Makassar, 24 Hebruari 2017.

${ }^{3}$ Mashum, S.IP, Kepala Perpůstakaan Stikes Mega Reski Makassar, Wawancara, Makassar, 24 februari 2017.

${ }^{4}$ Zukmawaty, S.Sos, Pegawai Perpustakaan Stikes Mega Reski Makassar, Wawancara, Makassar, 24 Hebruari 2017

${ }^{4}$ Mashum, S.IP, Kepala Perpulstakaan Stikes Mega Reski Makassar, Wawancara, Makassar, 24 februari 2017. 
diadakan. Daftar ini pada umumnya dibuat dengan mempertimbangkan beberapa unsur yang dimulai dari intensitas penggunaanya dan keterbatasan eksemplarnya. Selain itu, penginventarisan koleksi bahan pustaka berupa buku diperpustakaan STIKES mega reski Makassar sudah berbasis Teknologi Informasi (TI) yaitu dengan melakukan pembubuhan stempel pada bagian-bagian tertentu pada buku dan selanjutnya melakukan pengimputan koleksi buku kedalam aplikasi slims yang terdapat didalam perangkat keras (komputer). Selanjutnya pemeliharaan bahan pustaka terlihat bahwa perpustakaan tidak melakukanya dalam perpustakaan melainkan membutuhkan jasa yang ada diluar perpustakaan. Alasanya karena jumlah tenaga kerja perpustakaan yang masih terbatas serta ketersediaan alat penjilidan bahan pustaka yang belum ada yang menjadi factor penghambat pemeliharaan koleksi buku perpustakaan di STIKES Mega Reski Makassar. Kemudian penyiangan yang dilakukan di Perpustakaan STIKES mega Reski Makassar didasari atas beberapa factor diantaranya koleksi yang sudah tidak terpakai lagi, dalam bahasan yang sudah tidak dikenal lagi pemustaka, bidang subjek yang sesuai untuk koleksi, jarang digunakan, serta jumlah copy yang terlalu banyak denga pengguna yang terbatas. Pelaksanaan penyiangan di Perpustakaan STIKES Mega Reski Makassar dilakukan 1 kali setahun namun terkadang juga tidak dilakukan sama sekali dalam setahun. 


\section{DAFTAR PUSTAKA}

Almah, Hildawati. Pemilihan dan Pengembangan Koleksi Perpustakaan Makassar: Alauddin Press, 2012.

Basuki, Sulistio-. Pengantar Ilmu Perpustakaan Jakarta: Gramedia. Pustaka Utama, 1991.

Basuki, Sulistyo-, Pengantar Ilmu Perpustakaan, Jakarta: Gramedia, 1999.

Hartono, Manajemen Perpustakaan Sekolah Yogyakarta: Ar-Ruzz Media, 2016.

Ibrahim, Andi. Pengantar Ilmu Perpustakaan dan Kearsipan.

Kohar, Ade. Teknik Kebijakan Pengembangan Koleksi Jakarta: Perpustakaan, 2013.

Noerhayati, S. Pengelolaan perpustakaan jilid II Bandung: Alumni, 1987.

Perpustakaan Nasional. 2009. Undang-Undang Ri Nomor 43 Tahun 2007 Tentang Perpustakaan (Jakarta: CV. Tamita Utama). h. 5

Rahayuningsih, F. Pengelolaan Bahan Pustaka, Yogyakarta: Graha ilmu, 2007.

Sutarno NS, Perpustakaan dan Masyarakat, Jakarta: Yayasan Obor Indonesia,2003.

Sutarno NS. Kamus Perpustakaan dan Informasi Jakarta: Jala, 2008.

Suwarno, Wiji. Organisasi Informasi Perpustakaan Pendekatan Teori dan Praktik Jakarta: Rajawali Pers, 2016.

Yulia, Yuyu. Kebijakan Pengembangan Koleksi Perpustakaan Jakarta: Perpustakaan Nasionala RI, 1993.

\section{Sumber Wawancara:}

Ma'shum, Kepala Perpustakaan Stikes Mega reski Makassar, Wawancara, Makassar, 24 Februari 2017.

Khoeruddin. Waka II Bidang Administrasi Umum dan Keuangan Stikes Mega Reski Makassar, Wawancara, 26 Februari 2017

Zukmawaty, S.Sos, Pegawai Perpustakaan Stikes Mega Reski Makassar, Wawancara, Makassar, 24 Hebruari 2017.

Nur. Staf Perpustakaan Stikes Mega Reski Makassar, Wawancara, Makassar, 24 Februari 2017

Dwi Nining Apriliani, mahasiswa S-I Farmasi, Wawancara, Makassar, 26 Februari 2017

Fathoanah Qiran Sakinah, Mahasiswi S-I Farmasi Stikes Mega Reski Makassar, Wawancara, Makassar, 26 Februari 2017

Julia Fitrianingsih. Wakil Ketua I Stikes Mega Reski Makassar, Wawancara, Makassar, 26 Februari 2017. 